\section{The Effect of Daminozide and Chlormequat on the Growth and Flowering of Poinsettia and Pansy}

\author{
Kelly P. Lewis, James E. Faust, and James D. Sparkman, IV \\ Department of Horticulture, E-143 P\&A Building, Clemson University, \\ Clemson, SC 29634-0375
}

\author{
Larry W. Grimes \\ Department of Experimental Statistics, 103 P\&A Building, Clemson University, \\ Clemson, SC 29634
}

Additional index words. height control, plant growth regulators, tank mix

\begin{abstract}
Poinsettia (Euphorbia pulcherrima Willd. Ex Klotzch) 'Freedom Red' (FR), 'Success Red' (SR), and 'Winter Rose Dark Red' (WRDR) and pansy (Viola wittrockiana Gams.) 'Colossus Yellow Blotch' (CYB), 'Delta Pure Yellow' (DPY), and 'Majestic Giants Purple' (MGP) were treated with 14 different tank mix combinations of daminozide and chlormequat ranging from 0 to $4500 \mathrm{mg} \cdot \mathrm{L}^{-1}$ daminozide and 0 to $1500 \mathrm{mg} \cdot \mathrm{L}^{-1}$ chlormequat. The tank mix treatments reduced stem elongation for all three poinsettia cultivars. Total bract area of FR and canopy bract diameter of WRDR decreased linearly as daminozide or chlormequat concentration increased, while bract area of SR was affected by daminozide alone. Anthesis was not delayed by any of the plant growth regulator (PGR) applications. For pansies, growth responses to the PGR treatments varied with cultivar. CYB growth was affected by daminozide alone, DPY growth was affected by daminozide and/or chlormequat, while MGP growth was relatively insensitive to both PGRs. Time to flower of pansy was not affected by the PGR applications. Chemical names used: 2chloroethyl $N, N, N$-trimethylammonium chloride (chlormequat chloride); butanedioic acid mono (2,2-dimethylhydrazide) (daminozide).
\end{abstract}

During July through September, poinsettia and fall pansy crops are typically grown in commercial facilities at relatively warm temperatures. Consequently, plant growth is vigorous, so height control is challenging. Excessively tall plants are more expensive to transport due to the increased shelf height on the trucks. The market specifications often include target plant heights, so the ability to control stem elongation is critical to the success of commercial growers. Many methods for height control have been suggested for greenhouse crops, including mechanical stress (Garner and Langton, 1997), differential day and night temperatures (Berghage and Heins, 1991; McAvoy, 1992), and chemical plant growth regulators (PGRs) (Bailey and Miller, 1991; Barrett et al., 1994; Fisher et al., 1996; Holcomb and Rose, 1990).

Growers use tank mixes of two different products, or active ingredients, to reduce the labor required for applying chemicals or to increase the efficacy of the application. The most common tank mixes are the combination of two fungicides or two insecticides, however two PGRs can also be combined in a tank mix. The tank mix of daminozide (B-Nine, Uniroyal Chemical Co., Inc., Middlebury,

Received for publication 18 Apr. 2003. Accepted for publication $28 \mathrm{Dec}$. 2003. This material is based upon work supported by the CSREES/USDA, under project number SC-4951 and in conjunction with Uniroyal Chemical Company, Inc. Any opinions, findings, conclusions or recommendations expressed in this publication are those of the authors and do not necessarily reflect the view of the USDA.
Conn.) and chlormequat (Cycocel, Olympic Horticultural Products Co., Mainland, Pa.) has been effectively used to control height of many plant species (Faust and Lewis, 2003; Gibson and Whipker, 2003) and these two growth regulators have been reported to act synergistically (Uniroyal Chemical Co., Inc., 1998). The daminozide and chlormequat tank mix provides moderate PGR activity and is relatively easy to apply, i.e., application volume and technique are not critical. In contrast, highly active PGRs, such as paclobutrazol and uniconazole, can produce excessive height control, and their activity is greatly affected by the application volume and technique. Therefore, a daminozide and chlormequat tank mix is considered to be a moderate PGR treatment with the potential effectiveness positioned between daminozide or chlormequat and paclobutrazol or uniconazole.

For poinsettia, the suggested combinations of daminozide and chlormequat range from 800 to $2500 \mathrm{mg} \cdot \mathrm{L}^{-1}$ daminozide and from 1000 to $1500 \mathrm{mg} \cdot \mathrm{L}^{-1}$ chlormequat (J. Barrett, personal communication). The chlormequat product label advises to avoid concentrations greater than $2500 \mathrm{mg} \cdot \mathrm{L}^{-1}$ daminozide $/ 1500$ $\mathrm{mg} \cdot \mathrm{L}^{-1}$ chlormequat on poinsettia, and this concentration should only be applied to stock plants during the summer (Olympic Horticultural Products Co., 1996). Bailey and Miller (1991) reported that an application of 2500 $\mathrm{mg} \cdot \mathrm{L}^{-1}$ daminozide $/ 1500 \mathrm{mg} \cdot \mathrm{L}^{-1}$ chlormequat spray made to poinsettias 1 week before start of short days delayed anthesis by $3 \mathrm{~d}$.

The individual rates and ratio of dami- nozide-to-chlormequat used in tank mixes by commercial growers vary considerably, generating much speculation concerning the interactive effects of these two products. Therefore, the objectives of this study were 1) to determine the effect of daminozide and chlormequat tank mixes on the growth and flowering of two important floriculture crops, poinsettia and pansy, and 2) to determine the potential for developing a pre-blended daminozide and chlormequat product.

\section{Materials and Methods}

Poinsettia. Rooted cuttings of 'Freedom Red' (FR), 'Success Red' (SR), and 'Winter Rose Dark Red' (WRDR) were received from a commercial propagator (Paul Ecke Ranch, Encinitas, Calif.) and potted into 10-cm-diameter (454-mL) standard pots using a peat-based medium (Fafard 3B; Fafard Inc., Anderson, S.C.) on 26 July. Unpinched plants were grown at $30.5 \times 30.5 \mathrm{~cm}$ spacing to simulate commercial methods. One plant was grown per container. Fourteen growth regulator combinations were tested. Three treatments had a 1:1 daminozide $\left(\mathrm{mg} \cdot \mathrm{L}^{-1}\right)$-to-chlormequat $\left(\mathrm{mg} \cdot \mathrm{L}^{-1}\right)$ ratio $(500 / 500,1000 / 1000,1500 / 1500)$, three treatments had a $2: 1$ ratio $(1000 / 500,2000 / 1000$, $3000 / 1500)$ and three treatments had a $3: 1$ ratio $(1500 / 500,3000 / 1000,4500 / 1500)$. Five treatments were control groups where the daminozide and/or the chlormequat concentrations were $0(0 / 0,0 / 1000,0 / 1500,2000 / 0,4500 / 0)$. The spray applications were made at 0700 $\mathrm{HR}$ using a $\mathrm{CO}_{2}$ backpack sprayer at a rate of $0.81 \mathrm{~L} \cdot \mathrm{m}^{-2}$.

The 14 growth regulator treatments made up an incomplete factorial arrangement, with seven plants per treatment. The experiment was repeated on 2 consecutive days (14 and 15 Aug.) for a total of 14 plants for each chemical combination. Separate PGR solutions were mixed for each day. Individual plants were completely randomized within each replication. Plants were grown in a double-polyethylene greenhouse. Night temperatures averaged $21^{\circ} \mathrm{C}$, and the day temperatures averaged $26{ }^{\circ} \mathrm{C}$ over the duration of the experiment. The average daily light integral delivered to the plant canopy during the course of the experiment was 15.3 $\mathrm{mol} \cdot \mathrm{m}^{-2} \cdot \mathrm{d}^{-1}$, calculated by multiplying outside irradiance by the greenhouse photosynthethic photon flux transmission percentage. A constant liquid fertilization program was used where a $300 \mathrm{mg} \cdot \mathrm{L}^{-1} \mathrm{~N}$ solution from $15 \mathrm{~N}-2.2 \mathrm{P}-12 \mathrm{~K}$ Peter's Excel or 20N-8.6P-16.6K Peat-Lite Special (O.M. Scott, Marysville, Ohio) was alternated weekly. Short days were initiated on the day that the PGR applications were made and continued throughout the duration of the experiment by covering the plants with black cloth at $1700 \mathrm{HR}$ and removing at 0800 HR the following morning. Short days were provided at the time of the PGR treatments since commercial applications typically occur near the time of flower initiation, and applications made near the time of flower initiation have the potential to affect the time to flower and bract size (Bailey and Miller, 1991).

The date of first bract color and anthesis 
was recorded for each plant. A destructive harvest was conducted on individual plants as they reached anthesis. Plant height, shoot fresh weight, total bract area, bract petiole length, and transitional bract internode length were recorded at harvest. Shoot fresh weight consisted of all plant tissue above the growing medium. Bract area of the three acropetal transitional bracts and the three primary true bracts was recorded with a leaf area meter (LI-3000; LI-COR, Inc. Lincoln, Neb). Transitional bracts are defined as the green leaves that change to red as the plant matures. True bracts are the three primary bracts that occur in the whorl subtending the cyathium and are red when first visible. Total bract area is the sum of the area of the three true and three transitional bracts. The bract area of WRDR could not be measured with a leaf area meter because of the curved bracts, so the bract canopy diameter was measured as described by

\section{A. Freedom}

$\mathrm{y}=(\mathrm{D} *-1.20 \mathrm{E}-03)+(\mathrm{C} *-3.48 \mathrm{E}-03)+(\mathrm{D} * \mathrm{C} * 6.26 \mathrm{E}-07)+26.5$

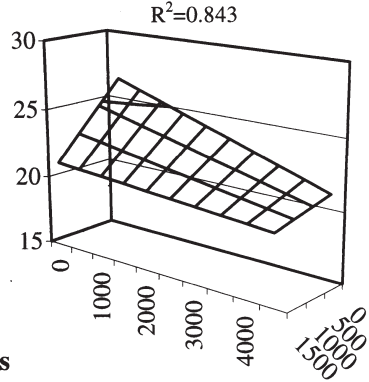

B. Success

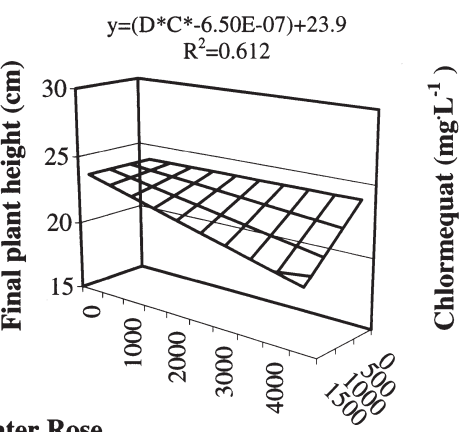

C. Winter Rose

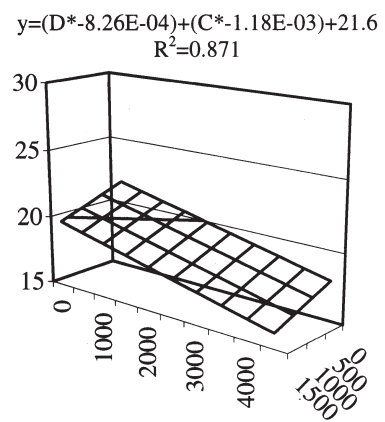

Daminozide $\left(\mathrm{mg} \cdot \mathrm{L}^{-1}\right)$

Fig. 1. Effect of daminozide and chlormequat on plant height of poinsettia (A) 'Freedom Red', (B) 'Success Red', and (C) 'Winter Rose Dark Red'. Data were collected when individual plants reached anthesis. The surfaces represent the results of stepwise regression analysis. The equation for each surface is shown above each figure, where $\mathrm{D}$ indicates daminozide and $\mathrm{C}$ indicates chlormequat.
Bailey and Miller (1991). Petiole lengths were recorded for the three transitional and three true bracts. Internode length was recorded above the three nodes associated with the three acropetal transitional bracts.

Pansy. Plugs ( $\left.1.9 \mathrm{~cm}^{2}, 9.5 \mathrm{~mL}\right)$ of 'Colossus Yellow Blotch' (CYB), 'Delta Pure Yellow' (DPY), and 'Majestic Giants Purple' (MGP) were received from a commercial grower (Wagner's Greenhouses, Minneapolis) and were potted on 16 Aug. in the same medium and container types as the poinsettias. Plants were grown at $10 \times 10 \mathrm{~cm}$ spacing to simulate commercial production methods. The experiment was repeated on 2 consecutive days. On day one of each replication, 168 plants were divided into 14 treatments, each containing 12

\section{A. Freedom} $\mathrm{y}=(\mathrm{D} *-1.46 \mathrm{E}-03)+\left(C^{*}-2.72 \mathrm{E}-03\right)+49.5$ $\mathrm{R}^{2}=0.832$

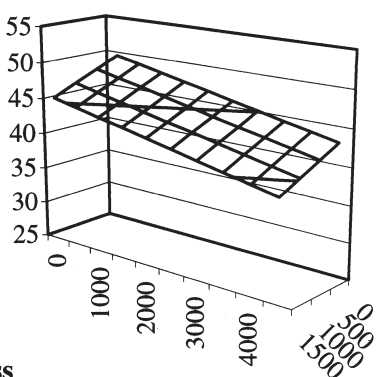

B. Success

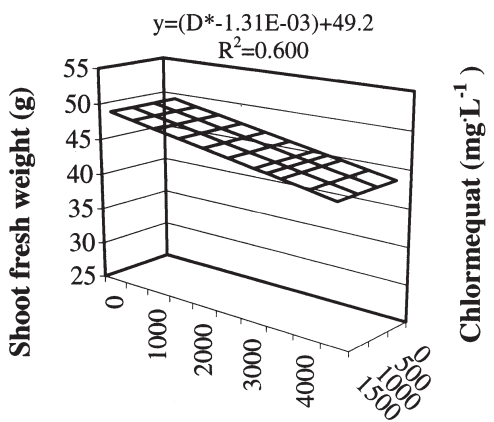

\section{Winter Rose}

$\mathrm{y}=(\mathrm{D} *-7.96 \mathrm{E}-04)+(\mathrm{C} *-9.96 \mathrm{E}-07)+44.5$

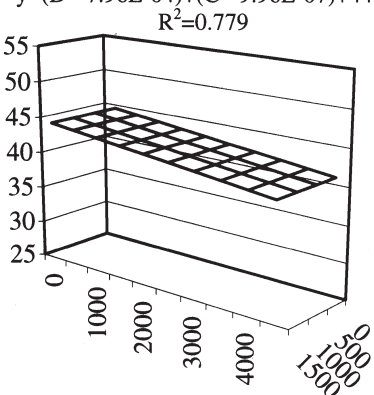

Daminozide $\left(\mathrm{mgL}^{-1}\right)$

Fig. 2. Effect of daminozide and chlormequat on shoot fresh weight of poinsettia (A) 'Freedom Red', (B) 'Success Red', and (C) 'Winter Rose Dark Red'. Data were collected when individual plants reached anthesis. The surfaces represent the results of stepwise regression analysis. The equation for each surface is shown above each figure, where $\mathrm{D}$ indicates daminozide and $\mathrm{C}$ indicates chlormequat. plants. In the first replication, growth regulators were applied on 29 Aug., 5 Sept., and 13 Sept., and for the second replication, 30 Aug., 6 Sept., and 14 Sept. Separate PGR solutions were mixed for each application date. Individual plants were completely randomized within each replication. This was an incomplete factorial with 12 plants per treatment and replicated with two different series of application dates.

Liquid fertilization was applied weekly with 20N-8.6P-16.6K Peat-Lite Special (O.M. Scott, Marysville, Ohio) at $300 \mathrm{mg} \cdot \mathrm{L}^{-1} \mathrm{~N}$. Clear water was applied as needed the remainder of the week.

A destructive harvest was performed on individual plants when two flowers per plant were fully open. Data collected included primary stem length (i.e., the primary stem was held upright to measure the distance from the medium surface to the shoot apex), shoot

\section{A. Freedom}

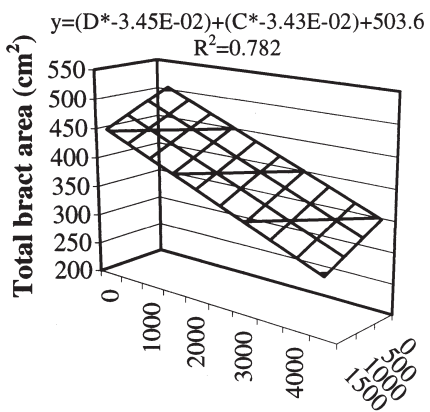

B. Success
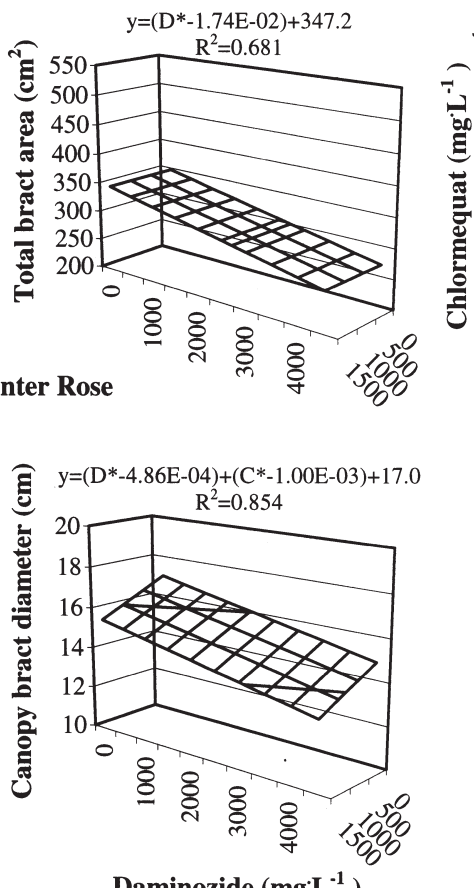

Fig. 3. Effect of daminozide and chlormequat on total bract area of poinsettia (A) 'Freedom Red', (B) 'Success Red', and (C) 'Winter Rose Dark Red'. Data were collected when individual plants reached anthesis. The surfaces represent the results of stepwise regression analysis. The equation for each surface is shown above each figure, where $\mathrm{D}$ indicates daminozide and $\mathrm{C}$ indicates chlormequat. 
fresh weight (i.e., all tissue above the media surface) and the number of lateral stems $>1$ $\mathrm{cm}$. Petiole lengths and leaf areas of the three largest leaves per plant were recorded. The date and diameters of first and second fully opened flowers were recorded.

Statistical analysis. Stepwise regression analysis was performed on the means for each replication using PROC REG (SAS Institute, Inc. Cary, N.C.). Terms considered in the analysis were the linear and quadratic components for each chemical and all the possible interactions. Non-significant terms $(p>0.20)$ were deleted from the model.

\section{Results and Discussion}

Poinsettia. Final plant height of FR de-

\section{A. Colossus Yellow Blotch}

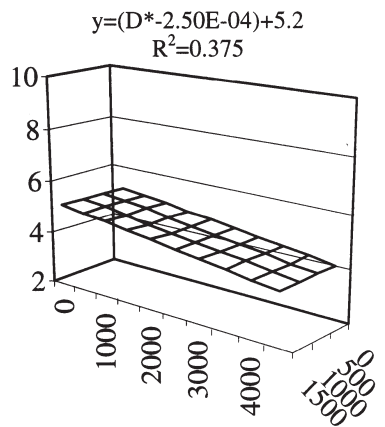

B. Delta Pure Yellow

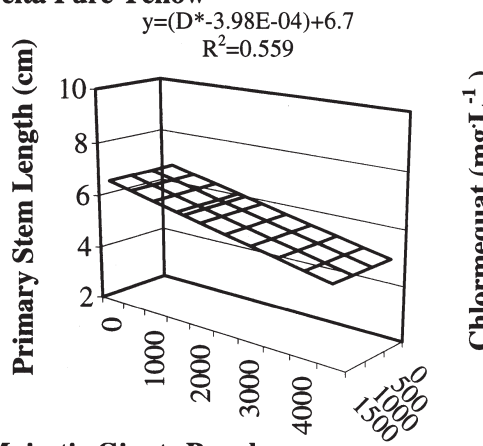

C. Majestic Giants Purple

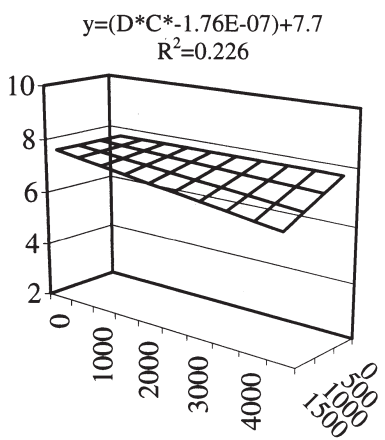

Daminozide $\left(\mathrm{mgL}^{-1}\right)$

Fig. 4. The effect of daminozide and chlormequat on the primary stem length of pansy (A) 'Colossus Yellow Blotch', (B) 'Delta Pure Yellow', and (C) 'Majestic Giants Purple'. Data were collected when two flowers were fully opened on individual plants. The surfaces represent the results of stepwise regression analysis. The equation for each surface is shown above each figure, where $\mathrm{D}$ indicates daminozide and $\mathrm{C}$ indicates chlormequat. creased as daminozide or chlormequat concentration increased, however little additional control of stem elongation occurred when one PGR was added to the other in the tank mix combinations (Fig. 1A). SR height showed an interactive effect of the two PGRs (Fig. 1B). WRDR height decreased linearly as daminozide or chlormequat concentration increased, and no interaction was observed (Fig. 1C). The final plant height was $6.4,4.4$, and $5.5 \mathrm{~cm}$ shorter for FR, SR, and WRDR, respectively, for the $4500 / 1500 \mathrm{mg} \cdot \mathrm{L}^{-1}$ daminozide/chlormequat tank mix treatment compared to the control $\left(0 / 0 \mathrm{mg} \cdot \mathrm{L}^{-1}\right.$ daminozide/chlormequat tank mix).

Shoot fresh weight of FR decreased linearly as daminozide or chlormequat increased, while SR and WRDR were affected only by daminozide (Fig. 2A-C). Total bract area of FR and canopy bract diameter of WRDR de-

\section{A. Colossus Yellow Blotch}

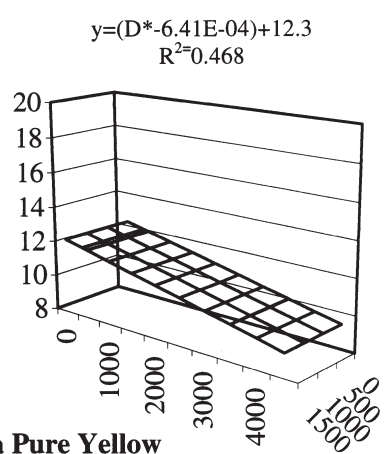

B. Delta Pure Yellow

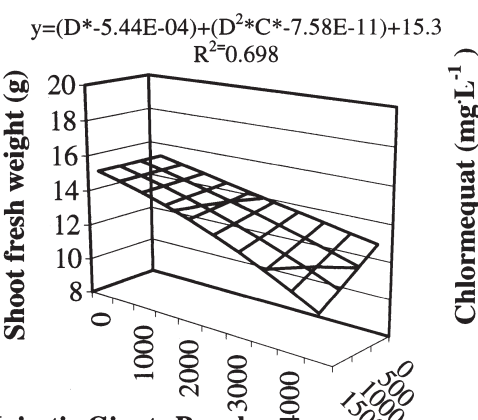

C. Majestic Giants Purple

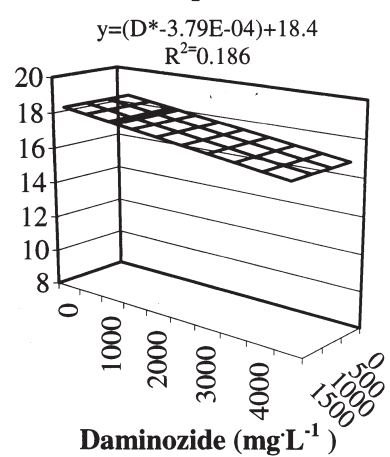

Fig. 5. The effect of daminozide and chlormequat on shoot fresh weight of pansy (A) 'Colossus Yellow Blotch', (B) 'Delta Pure Yellow', and (C) 'Majestic Giants Purple'. Data were collected when two flowers were fully opened on individual plants. The surfaces represent the results of stepwise regression analysis. The equation for each surface is shown above each figure, where $\mathrm{D}$ indicates daminozide and $\mathrm{C}$ indicates chlormequat. creased linearly as daminozide or chlormequat increased, while SR was only by daminozide (Fig. 3A-C).

Petiole length of FR and SR was 4.4 and $6.7 \mathrm{~mm}$ shorter, respectively, for the $4500 / 1500$ $\mathrm{mg} \cdot \mathrm{L}^{-1}$ tank mix treatment compared to the control (data not shown). Petiole length of WRDR was $2.4 \mathrm{~mm}$ shorter for the 4500 $\mathrm{mg} \cdot \mathrm{L}^{-1}$ daminozide application compared to the control, while chlormequat had no significant effect. Internode length of the stem associated with the transitional bracts was not significantly affected by daminozide or chlormequat. Time to first color of SR was delayed by $2 \mathrm{~d}$ with the $4500 \mathrm{mg} \cdot \mathrm{L}^{-1}$ daminozide application (data not shown), while no other PGR treatment delayed time to first color. Time of anthesis was not significantly affected by daminozide or chlormequat for any of the three cultivars.

A. Colossus Yellow Blotch

B. Delta Pure Yellow

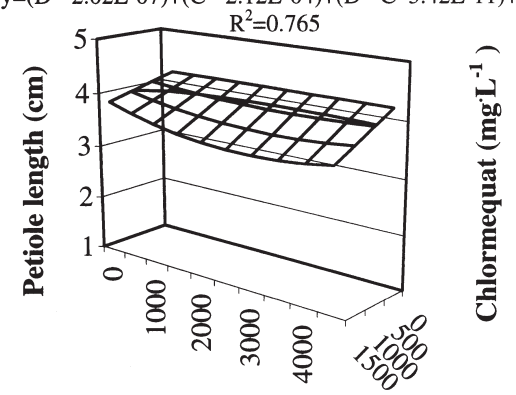

C. Majestic Giants Purple

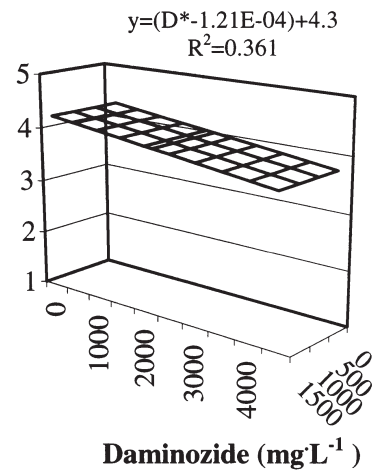

Fig. 6. The effect of daminozide and chlormequat on petiole length of pansy (A) 'Colossus Yellow Blotch', (B) 'Delta Pure Yellow', and (C) 'Majestic Giants Purple'. Data were collected when two flowers were fully opened on individual plants. The surfaces represent the results of stepwise regression analysis. The equation for each surface is shown above each figure, where $\mathrm{D}$ indicates daminozide and $\mathrm{C}$ indicates chlormequat. 
For poinsettia, tank mixes applied at the start of short days effectively reduced stem elongation; however, a relatively large reduction in bract area was also observed. The PGR treatments produced shorter bract petioles resulting in a smaller bract canopy diameter. The total bract area of the untreated control demonstrates that FR is a relatively large-bracted cultivar while SR is a relatively small-bracted cultivar. Smaller bract size can be acceptable for largebracted cultivars; however, little bract reduction is acceptable for small-bracted cultivars. All of the treatments in this study produced total bract areas $>250 \mathrm{~cm}^{2}$, which was commercially acceptable. Even though the PGR treatments did not affect the anthesis date, the market date may be delayed by a few days as a result of the decreased bract area since the PGR-treated plants may require more time to achieve a commercially acceptable bract area.

Leaf color data were not collected in this study, but it was apparent that daminozide significantly intensified the dark green pigmentation in poinsettia leaves. Daminozide is not frequently applied alone on commercial poinsettia crops; however, our data suggests that daminozide alone would be a particularly effective treatment on poinsettia stock plants where the focus is to produce a toned cutting with dark green leaves.

In this study, we observed phytotoxicity in the form of chlorotic spots on WRDR leaves occurring $2 \mathrm{~d}$ following the $0 / 1500$ $\mathrm{mg} \cdot \mathrm{L}^{-1}$ daminozide/chlormequat applications. Treatments with the same chlormequat concentration and varying rates of daminozide, e.g., 1500/1500, 3000/1500, and 4500/1500 $\mathrm{mg} \cdot \mathrm{L}^{-1}$ daminozide/chlormequat, displayed no phytotoxicity. Thus, the tank mix appears to reduce poinsettia sensitivity to chlormequat phytotoxicity. It is possible that tank mixing daminozide and chlormequat could allow for the application of higher rates of chlormequat without causing phytotoxicity. Further experimentation is warranted.

Pansy. The growth responses of pansies to the PGR treatments was highly dependent on cultivar, while the time to first and second open flower was not affected by the PGR treatments for any of the cultivars. The growth of CYB responded only to daminozide (Figs. 4A, $5 \mathrm{~A}$, and $6 \mathrm{~A}$ ). Increasing daminozide from 0 to $4500 \mathrm{mg} \cdot \mathrm{L}^{-1}$ on $\mathrm{CYB}$ resulted in a $1.1 \mathrm{~cm}$ shorter primary stem length, a $1.0 \mathrm{~cm}$ shorter petiole length, and a $3.9 \mathrm{~cm}^{2}$ smaller leaf area. Lateral stem number of CYB was not affected by the tank mixes.

The primary stem length of DPY responded to daminozide, while shoot fresh weight and petiole length responded to daminozide and chlormequat (Figs. 4B, 5B, and 6B). Primary stem length was $1.8 \mathrm{~cm}$ shorter for DPY as daminozide increased from 0 to $4500 \mathrm{mg} \cdot \mathrm{L}^{-1}$, while the shoot fresh weight decreased $4.8 \mathrm{~g}$ for the $4500 / 1500 \mathrm{mg} \cdot \mathrm{L}^{-1}$ tank mix compared to the control. Leaf area of DPY was 1.9 $\mathrm{cm}^{2}$ smaller when treated with $1500 \mathrm{mg} \cdot \mathrm{L}^{-1}$ chlormequat compared to the control (data not shown). Lateral stem number of DPY increased from 3.8 to 4.7 stems per plant as daminozide increased from 0 to $4500 \mathrm{mg} \cdot \mathrm{L}^{-1}$, while chlormequat had no effect (data not shown). MGP displayed statistically significant growth responses to the PGR treatments, however the magnitude of the responses were commercially insignificant and the $R^{2}$ values were low (Figs. 4C, 5C, and 6C).

Other PGRs, such as paclobutrazol and uniconazole are more effective on pansy than daminozide and chlormequat, however over-application can result in stunting, so daminozide and chlormequat are a viable option for commercial growers. However, the multiple applications required to produce the moderate growth regulating effect observed in this study are likely to make the daminozide and chlormequat tank mix a more expensive application than paclobutrazol or uniconazole. For example, the cost for a single application of $4500 \mathrm{mg} \cdot \mathrm{L}^{-1}$ daminozide $/ 1500 \mathrm{mg} \cdot \mathrm{L}^{-1}$ chlormequat was estimated at $\$ 1.40 / \mathrm{L}$ compared to $\$ 0.25$ for $10 \mathrm{mg} \cdot \mathrm{L}^{-1}$ paclobutrazol or $\$ 0.64$ for $5 \mathrm{mg} \cdot \mathrm{L}^{-1}$ uniconazole (R. Heins, personal communication).

Considering the large number of commercial varieties of poinsettias and pansies and the rate of cultivar turnover from year to year, the criterion for developing a useful preblended tank mix product is that the product provides a measure of effectiveness across a range of species and cultivars. Our data demonstrate that daminozide/chlormequat tank mixes provide a response equal to or greater than applying one or the other PGR and may work across a wider range of cultivars than either PGR alone.

For poinsettias, the $3: 1$ ratio treatments of $1500 / 500,3000 / 1000$, and $4500 / 1500 \mathrm{mg} \cdot \mathrm{L}^{-1}$ daminozide/chlormequat provided low, medium and high rates of effectiveness. For two of the three pansy cultivars, multiple applications of the $3000 / 1000 \mathrm{mg} \cdot \mathrm{L}^{-1}$ daminozide/chlormequat tank mix provided a relatively low rate of effectiveness, while the $4500 / 1500 \mathrm{mg} \cdot \mathrm{L}^{-1}$ daminozide/chlormequat tank mix provided a medium rate of effectiveness. Thus, a 3:1 daminozide-to-chlormequat tank mix provides a commercially acceptable growth regulating effect, even though the specific responses are highly dependent on species and cultivar. A preblended product using a 3:1 daminozide-tochlormequat ratio has the potential to provide a useful commercial product.

\section{Literature Cited}

Bailey, D.A. and W.B. Miller. 1991. Poinsettia developmental and postproduction responses to growth retardants and irradiance. HortScience 26(12):1501-1503.

Barrett, J.E., C.A. Bartuska, and T.A. Nell. 1994. Comparison of paclobutrazol drench and spike applications for height control of potted floriculture crops. HortScience 29(3):180-182.

Berghage, R.D. and R.D. Heins. 1991. Quantification of temperature effects on stem elongation in poinsettia. J. Amer. Soc. Hort. Sci. 116(1):14-18.

Faust, J. and K. Lewis. 2003. Tank-mixing PGRS. Greenhouse Prod. News 13(2):42-47.

Fisher, P.R., R.D. Beins, and J.H. Lieth. 1996. Modeling the stem elongation response ofpoinsettia to chlormequat. J. Amer. Soc. Hort. Sci. 121(5):861-868.

Garner, L.C. and F.A. Langton. 1997. Brushing pansy (Viola tricolor L.) transplants: A flexible, effective method for controlling plant size. Sci. Hort. 70:187-195

Gibson, J.L. and B.E. Whipker. 2003. Efficacy of plant growth regulators on the growth of vigorous Osteospermum cultivars. HortTechnology 13:132-135.

Holcomb, E.J. and M.A. Rose. 1990. Height control of selected bedding plants with uniconazole. Acta. Hort. 272:279-284

McAvoy, R.J. 1992. In situ plant canopy and potting medium temperatures under two greenhouse temperature regimes. HortScience 27(8):918-920.

Olympic Horticultural Products. 1998. Product label \# 981660. Mainland, Pa.

Uniroyal Chemical Company, Inc. 1998. Product label \#004WPS. Middlebury, Conn. 